\title{
AN ASSESSMENT OF THE NET ECOSYSTEM METABOLISM AND RESPIRATION OF A TROPICAL CORAL REEF
}

\author{
Pramneechote, P. ${ }^{1,2}$ - SinutoK, S. ${ }^{2,3}$ - WongKamhaeng, K. ${ }^{4}$ - ChOtIKARN, P..$^{1,2 *}$ \\ ${ }^{I}$ Marine and Coastal Resources Institute, Prince of Songkla University, Kho Hong, Hat Yai, \\ Songkhla 90110, Thailand \\ ${ }^{2}$ Coastal Oceanography and Climate Change Research Center, Prince of Songkla University, \\ Kho Hong, Hat Yai, Songkhla 90110, Thailand \\ ${ }^{3}$ Faculty of Environmental Management, Prince of Songkla University, Kho Hong, Hat Yai, \\ Songkhla 90110, Thailand \\ ${ }^{4}$ Department of Zoology, Faculty of Science, Kasetsart University, Bangkok 10900, Thailand \\ *Corresponding author \\ e-mail: ponlachart.c@psu.ac.th; phone: +66-74-282-335; fax: +66-74-212-782 \\ (Received $29^{\text {th }}$ Oct 2019; accepted $30^{\text {th }}$ Jan 2020)
}

\begin{abstract}
The article aimed to assess the net ecosystem metabolism (NEM), and photosynthesis performance of Pocillopora acuta coral on the reef flat and reef slope of the southeast fringing reef of Phuket, Thailand, from June 2017 to January 2018, using 30 x 45-cm benthic oxygen flux chambers and a Junior Pulse Amplitude Modulated fluorometer. The results showed the NEM at both sites was significantly higher in the dry season. The effective quantum yield of P. acuta on the reef slope was significantly higher than that of the reef flat in both seasons. The maximum quantum yield showed seasonal variation, which was significantly higher on the reef slope during the dry season than that in the wet season. This study demonstrated temporal and spatial variations in ecosystem metabolism and photosynthetic activity due to different physical characteristics, such as light intensity, which is the main driver of coral reef ecosystem and different biological characteristics, such as the percentage of live coral, the number of microalgae and the symbiont density. The results provide a better understanding of how $P$. acuta responds to changes in depth and season and why corals on reef slopes might be more susceptible to bleaching than corals on reef flats.
\end{abstract}

Keywords: coral metabolisms, oxygen evolution, benthic chamber, photosynthetic capacity, zooxanthellae

\section{Introduction}

Coral reefs are among the most productive and biologically diverse ecosystems in the world (Slavov et al., 2016), with a gross primary productivity of 1-15 $\mathrm{g} \mathrm{C} \mathrm{m}^{-2}$ day $^{-1}$ ( $c a$. 0.4-5.5 kg C m year $^{-1}$ ) (Douglas, 2010). Coral reefs cover $600,000 \mathrm{~km}^{2}$ of the earth's surface or $0.1-0.5 \%$ of the ocean surface (Crossland et al., 1991; Moberg and Folke, 1999). Coral reef ecosystems are constructed by reef-building scleractinian corals (Buddemeier et al., 2004), coralline algae and other calcifying organisms (Smith et al., 2006), providing an important habitat for many marine organisms, such as microalgae, macroalgae, molluscs, crustaceans, and vertebrates, including fish and marine mammals (Harrison and Booth, 2007). Coral reefs support a huge number of people with goods and services in the form of food production, coastal protection and tourism, and provide ecosystem services with a value of $36,794 \$ \mathrm{ha}^{-1} \mathrm{yr}^{-1}$ to $2,129,122 \$ \mathrm{ha}^{-1} \mathrm{yr}^{-1}$ (Costanza et al., 2014). Scleractinian corals are major contributors to the productivity of coral reef ecosystems (Lesser, 2011). However, many coral reefs are suffering serious decline due 
to global climate change and human activities, such as overfishing, agricultural run-off, deforestration that increases soil erosion and runoff then increases sediment load into coral reef, tourism, and industrialization (Moberg and Folke, 1999; Hughes, 2008).

Since the last century, an increase in global temperatures caused by the rising $\mathrm{CO}_{2}$ concentration in the atmosphere has led to a $0.6^{\circ} \mathrm{C}$ increase in seawater temperature (Solomon et al., 2007). Elevated sea temperatures can result in a rise in sea level due to the changing of density and volume of water and the melting of the polar ice caps. Moreover, increases in temperature also increase precipitation and evaporation, which leads to more frequent and intense storms (Emanuel, 2005). Further, reductions in $\mathrm{pH}$ and $\mathrm{CO}_{3}{ }^{2-}$ ions, which are essential for calcification $\left(\mathrm{CaCO}_{3}\right.$ deposition), affect a range of marine organisms including scleractinian corals. Many studies have shown that ocean warming causes coral bleaching, the expulsion of symbiotic dinoflagellates (zooxanthellae) from coral tissue, and influences the health and survivorship of scleractinian corals (Jokiel et al., 2008; Randall and Szmant, 2009). Other environmental stresses include forms of marine pollution, such as nutrient enrichment and sedimentation, have also been found to reduce growth, increase mortality, and cause bleaching in coral worldwide (Alva-Basurto and Arias-González, 2014).

The aquatic light environment plays a major role in the productivity, physiology and ecology of corals (Mass et al., 2010). Light intensity decreases and light quantity (spectrum) changes with increasing depth. Zooxanthellae are capable of photoacclimation to different light regimes (Mass et al., 2010). Photoacclimation includes changes in chlorophyll pigment concentrations, chloroplast volume, the number and length of thylakoids, and the light utilization efficiency of photosynthesis and respiration (Mass et al., 2010). Exposure to high irradiance also leads to photoinhibition, a down-regulation of the photosynthetic process ( $\mathrm{Li}$ et al., 2018) and coral bleaching (Lesser, 2011). These processes could result in changes to the productivity of corals.

There are many types of coral response to seasonal and spatial variation which include changes in pigment, photosynthesis and metabolism. Fitt et al. (2000) and Warner et al. (2002) found a similar pattern of response with season in biomass, zooxanthellae density and photosynthetic rate, which are lowest during summer and highest during winter, whereas metabolism shows the opposite trend (Kayanne et al., 2005; Falter et al., 2012). Coral at different depths has also demonstrated spatial variation with the highest variation of maximum quantum yield $\left(\mathrm{F}_{\mathrm{v}} / \mathrm{F}_{\mathrm{m}}\right)$ found in coral at 1-2 $\mathrm{m}$ depth, but coral at 3-4 and $14 \mathrm{~m}$ had higher values (Warner et al., 2002).

Mass coral bleaching has been a major issue in Thailand for decades and some threatened areas have not yet recovered (Yeemin et al., 2013). Many studies have shown that coral bleaching, the loss of endosymbiotic dinoflagellates associated with coral, is caused by thermal and light stress leading to photoinhibition, which damages chloroplasts and photosynthetic apparatus, resulting in oxidative stress (the production and accumulation of reduced oxygen species) (Lesser, 2011; Downs et al., 2013). Coral bleaching is different from seasonal variation in zooxanthellae density, and the number of functional photosystem II (PSII) reaction centers (Lesser, 2011). It has been suggested that the frequency and intensity of bleaching increases with anthropogenic climate change. The susceptibility of corals to bleaching varies greatly among coral genera and reef areas (Pratchett et al., 2013). It has been found that symbiont density is a function of environmental conditions (e.g., nutrient pollution, irradiance), whilst the 
susceptibility to bleaching increases in corals with higher symbiont densities (Cunning and Baker, 2013).

A reduction in coral growth, increased mortality, and coral bleaching can lead to the degradation and loss of biological diversity of the reefs, which can affect the structure and functions of coral reef ecosystems. Therefore, it is important to identify which reef areas and coral species are most resilient to the effects of global climate change and other disturbances in order to support coral reef management (Cunning and Baker, 2013). Mass coral bleaching has been a major issue in Phuket but the ecophysiology of corals and zooxanthellae from this area has not often been investigated (Yeemin et al., 2013). The measurement of photosynthesis and ecosystem metabolism of coral is essential to understanding these threatened species. Understanding the ecophysiology of corals and zooxanthellae under different environmental conditions is important for predicting the potential for, severity, and consequences of coral bleaching.

The aim of this study was to investigate seasonal variation (wet and dry) in ecosystem metabolism and photosynthesis of corals at two depths. This study will provide a better understanding of how coral species respond to changes in depth and season and which corals are more susceptible to bleaching.

\section{Materials and methods}

\section{Study site}

Phuket Island is located in the southern part of Thailand, on the Andaman Sea coast. The island is partly fringed by reefs with a total area of about 6 square kilometers of reef. The study site is located on the southeastern tip of Phuket Island (Fig. 1) (Panwa Cape: $\left.7^{\circ} 48^{\prime} 06.9^{\prime \prime} \mathrm{N}, 98^{\circ} 24^{\prime} 24.4^{\prime \prime} \mathrm{E}\right)$. The reef is characterized by extensive reef flats that extend up to $200 \mathrm{~m}$ from shore (Brown et al., 2002) with a depth that increases at the reef edge $(5 \mathrm{~m})$.
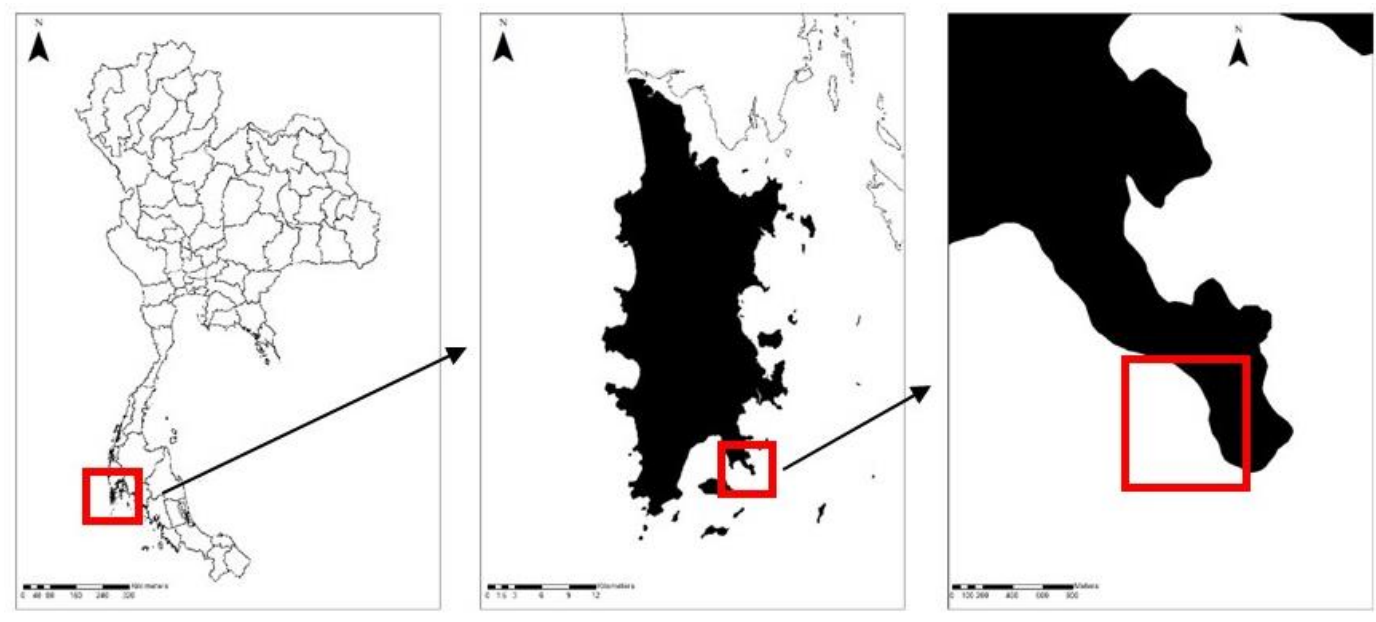

Figure 1. Panwa Cape, Phuket Province, Thailand

In this study, three photographic transects (Jokiel et al., 2015) were placed next to each other parallel to the shoreline in two areas (reef flat and reef slope) to determine the coral percentage cover and the number and types of substrate (e.g. coral, coral 
rubble, sand, rocks, algae) at Panwa Cape, Phuket Province (Fig. 1) (Panwa Cape: $\left.7^{\circ} 48^{\prime} 06.9^{\prime \prime} \mathrm{N}, 98^{\circ} 24^{\prime} 24.4^{\prime \prime E}\right)$ in June 2017 using Coral Point Count with Excel extensions (CPCe) (Kohler and Gill, 2006). A digital camera with a wide-angle lens was used to obtain the images by positioning the camera above a $0.25 \mathrm{~m}^{2}$ quadrat every $50 \mathrm{~cm}$ along the $30 \mathrm{~m}$ transect line without overlap. A total of 60 images per transect line were obtained covering a total of $45 \mathrm{~m}^{2}$ per area (Jokiel et al., 2015).

The primary productivity and photosynthetic activity of $P$. acuta from two depths at the same sampling site $\left(7^{\circ} 48^{\prime} 06.9^{\prime \prime} \mathrm{N}, 98^{\circ} 24^{\prime} 24.4^{\prime \prime} \mathrm{E}\right)$ were investigated from June 2017 to January 2018 using benthic oxygen flux chambers (three replicates/depth/month). The benthic oxygen flux chambers were modified from Olivé et al. (2016) and their design is described below and illustrated in Fig. 2. They were deployed for $3 \mathrm{~h}$ for incubation (Camp et al., 2015).
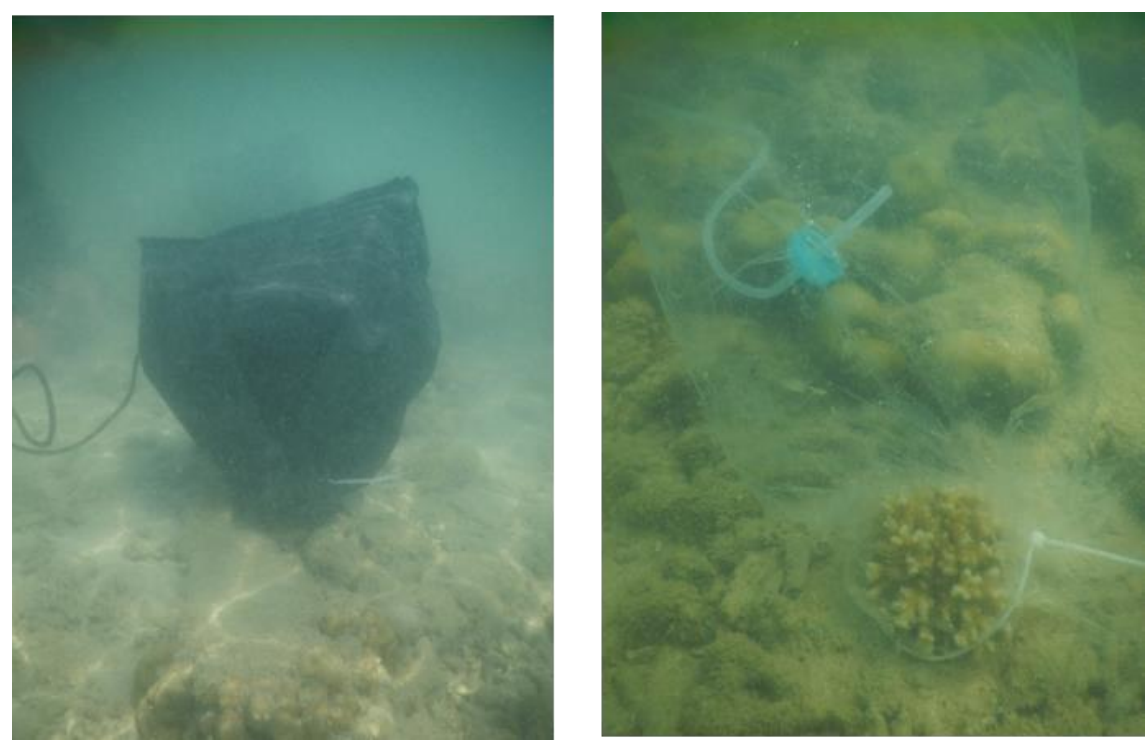

Figure 2. Dark (left) and light (right) benthic oxygen flux chamber $(n=3)$

Coral samples were collected at the same sampling site for photosynthetic measurements (four replicates/depth/time). Photosynthetic activity was investigated as chlorophyll fluorescence using a Junior Pulse Amplitude Modulated fluorometer (Junior-PAM: Walz GmbH, Effeltrich, Germany) in situ after which the coral samples were frozen and transported to the laboratory for analysis of their zooxanthellae density and pigment contents to support the photosynthesis data.

Physical and chemical parameters (e.g. light intensity, temperature, $\mathrm{pH}$, dissolved oxygen, salinity) from two depths from each time of sampling were determined using a YSI Pro Plus multiparameter meter (YSI Inc. / Xylem Inc, USA) and a Hobo data logger (OneTemp Pty Ltd, Australia).

\section{Productivity}

The productivity of $P$. acuta was investigated by determining the dissolved oxygen evolution in benthic chambers over time under light (transparent chamber) and dark (non-transparent chamber) conditions to determine the ecosystem respiration (Re), gross ecosystem metabolism (GEM) and net ecosystem metabolism (NEM). The benthic 
oxygen flux chambers consisted of $30 \mathrm{x} 45-\mathrm{cm}$ polypropylene cylinders accommodating a 6 liter-volume of water (Fig. 2), which was sufficient to measure the ecosystem metabolism without hypoxia during light or anoxia during darkness within a $3 \mathrm{~h}$ incubation period (Camp et al., 2015). The chambers were flexible due to the nature of the plastic bags from which they were constructed and allowed the propagation of external turbulence to the interior of the chambers (Barrón and Duarte, 2009). The benthic chambers were placed above the coral colony in situ and secured with a valve for water collection using a syringe to measure the dissolved oxygen concentration hourly. The GEM, NEM and Re were calculated using the standard equations (Eq.1 and Eq.2) following Olivé et al. (2016).

$$
\begin{gathered}
\mathrm{NEM}=\mathrm{GEM}-\mathrm{Re} \\
\mathrm{NEM} \text { or } \mathrm{Re}=\left[\left(\mathrm{O}_{2}\right)_{\text {final }}-\left(\mathrm{O}_{2}\right)_{\text {initial }}\right] /\left[(\mathrm{T})_{\text {final }}-(\mathrm{T})_{\text {initial }}\right]
\end{gathered}
$$

\section{Photosynthetic efficiency}

The photosynthetic activity of the coral-zooxanthellae was determined through the measurement of chlorophyll (Chl) $a$ fluorescence, zooxanthellae density and the photosynthetic pigment concentration. Photosynthetic performance was determined by performing rapid light curves (RLCs) using a junior-PAM fluorometer (Walz, Germany). RLCs with nine increasing actinic light intensities were applied with $0.8 \mathrm{~s}$ saturating pulses $\left(>4500 \mu \mathrm{mol}\right.$ photons $\left.\mathrm{m}^{-2} \mathrm{~s}^{-1}\right)$ between each actinic light intensity, every $10 \mathrm{~s}$. The effective quantum yield of PSII $\left(\Delta \mathrm{F} / \mathrm{F}_{\mathrm{m}} ;\right.$; Schreiber, 2004$), \mathrm{F}_{\mathrm{v}} / \mathrm{F}_{\mathrm{m}}$, maximum relative electron transport rate $\left(\mathrm{rETR}_{\max }\right)$, minimum saturating irradiance $\left(\mathrm{I}_{\mathrm{k}}\right)$ and initial slope $(\alpha)$ of the RLCs were calculated using curve fitting protocols following Ralph and Gademann (2005).

\section{Symbiont density and pigment contents}

The coral samples (nubbins) were airbrushed into $10 \mathrm{~mL}$ of $0.2-\mu \mathrm{m}$-filtered seawater to remove the tissue from the skeleton. The slurry was centrifuged at 4,000 rpm for 4 min to separate the symbiont cells from the animal tissue (Hill and Ralph, 2007). The supernatant containing animal tissue was discarded, and the symbiont pellet was resuspended in $10 \mathrm{~mL}$ of $0.2-\mu \mathrm{m}$-filtered seawater, then homogenized for $10 \mathrm{~s}$ at $15,000 \mathrm{rpm}$ and centrifuged again. The pellet was resuspended in $1 \mathrm{~mL}$ filtered seawater for cell counts and chlorophyll analyses. For zooxanthellae density analysis, four replicate cell counts were performed using a haemocytometer under a light microscope. The cell density was determined per $\mathrm{cm}^{2}$ following coral surface area calculations using the paraffin wax technique (Hill and Ralph, 2007). For the photosynthetic pigment concentration (chlorophyll (Chl) $a$ and $c_{2}$ ) analysis, the algal pellets were resuspended in $90 \%$ acetone and stored in darkness overnight at $4{ }^{\circ} \mathrm{C}$. After centrifugation, the chlorophyll $a$ and $c_{2}\left(\mu \mathrm{g} \mathrm{cm} \mathrm{cm}^{-2}\right)$ were then determined using the standard spectrophotometric method of Ritchie (2006) (Eqs.3 and 4), with absorbance measured at 630, 664 and $750 \mathrm{~nm}$ (Winters et al., 2009).

$$
\begin{aligned}
& \text { Chlorophyll } a=\left(-0.4574 \times \mathrm{A}_{630} \mathrm{~nm}\right)+\left(11.4754 \times \mathrm{A}_{664} \mathrm{~nm}\right) \\
& \text { Chlorophyll } c_{2}=\left(23.3900 \times \mathrm{A}_{630} \mathrm{~nm}\right)+\left(-3.5322 \times \mathrm{A}_{664} \mathrm{~nm}\right)
\end{aligned}
$$




\section{Water quality}

Physical and chemical parameters such as temperature, salinity, dissolved oxygen and $\mathrm{pH}$ were measured with a YSI Pro Plus multiparameter meter (YSI Inc. / Xylem Inc, USA) in both sites (reef flat and slope) and inside the benthic oxygen flux chambers at the initial time.

\section{Statistical analyses}

Two-way ANOVA was used to test for significant differences among depths over time in chlorophyll fluorescence parameters, percentage cover, productivity (GEM, NEM, Re), zooxanthellae density and pigment contents. Tukey's Honestly Significant Difference post-hoc test was used to identify the statistically distinct groups. All tests were performed with a significance level of $95 \%$. If the data did not meet the assumptions of normality (Kolmogorov-Smirnov test) and equal variance (Levene's test), the data was transformed using the square root or $\log _{10}$. If the transformed data did not meet the assumptions, non-parametric tests were used.

\section{Results}

\section{Coral diversity}

The results showed a total of 9 families and 17 genera on the reef flat and 12 families and 25 genera on the reef slope (Appendix Table 1). On the reef flat, the mean percentage cover of live corals, dead corals, sand and sponges were $43.93 \%, 51.64 \%$, $4.36 \%$ and $0.06 \%$, respectively (Fig. 3) and the dominant genus were Porites sp. $(31.38 \%)$, followed by Favites sp. (4.80\%) and Goniastrea sp. (3.35\%) (Fig. 4a). On the reef slope, the mean percentage cover of live corals, dead corals, sand and sponges were $21.65 \%, 62.53 \%, 15.44 \%$ and $0.38 \%$, respectively (Fig. 3 ) and the dominant genus were Porites sp. (5.05\%), followed by Acropora sp. (2.84\%) and Goniastrea sp. $(2.49 \%)$ (Fig. 4b). Shannon's diversity indexes of reef flat and reef slope were 1.13 and 2.67, respectively.

The coral status of the reef flat and slope were categorized as fair (25-49.9\%) and poor $(0-24.9 \%)$, respectively following the standard criteria for assessing the health of coral reefs (Madduppa and Zamani, 2011).

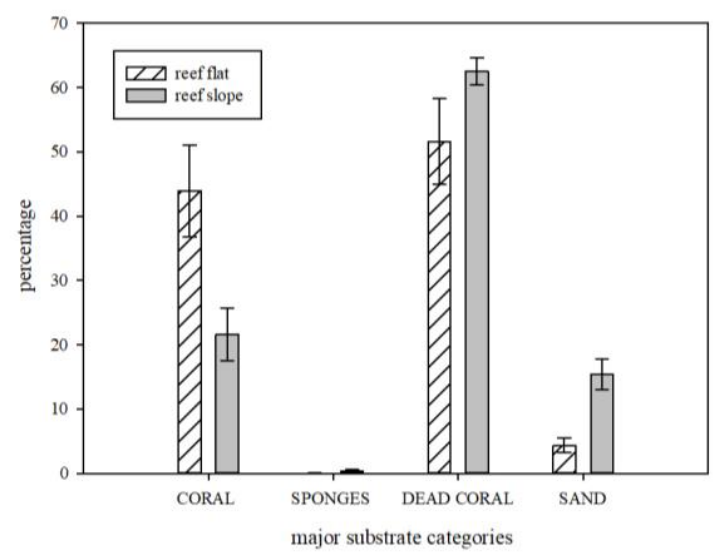

Figure 3. Major category of substrate from reefflat and reef slope. Data represents Mean $\pm S E$ $(n=3)$ 

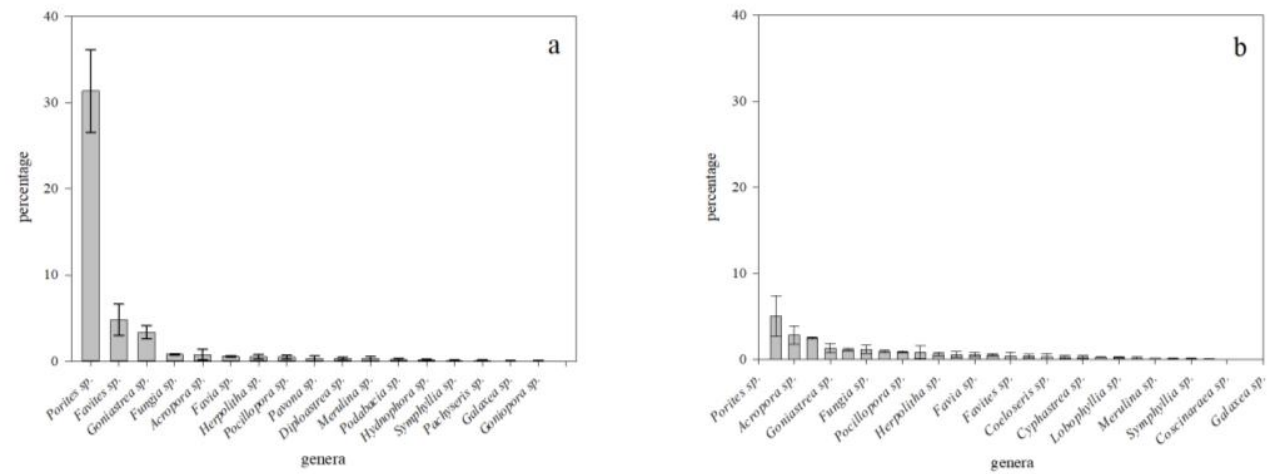

Figure 4. Percentage cover of coral genus from reefflat (a) and reef slope (b). Data represents Mean \pm SE $(n=3)$

\section{Primary productivity}

The GEM on the reef slope ranged from $281.44( \pm 63.95)$ to $994.47( \pm 167.33) \mathrm{mmol}$ $\mathrm{O}_{2} \mathrm{~m}^{-2} \mathrm{~d}^{-1}$ and $313.93( \pm 45.38)$ to $860.62( \pm 268.66) \mathrm{mmol} \mathrm{O}_{2} \mathrm{~m}^{-2} \mathrm{~d}^{-1}$ for the reef flat (Fig. 5b). The results, however were not significantly different between sites or seasons $(p>0.05)$. The NEM on the reef slope ranged from $184.07( \pm 71.02)$ to $867.41( \pm 206.84)$ mmol O$~_{2} \mathrm{~m}^{-2} \mathrm{~d}^{-1}$ and $130.32( \pm 18.79)$ to $646.69( \pm 239.39) \mathrm{mmol} \mathrm{O}_{2} \mathrm{~m}^{-2} \mathrm{~d}^{-1}$ for reef flat. On the reef slope, the NEM was significantly higher in the dry season $(p=0.01)$ (Appendix Table 2). The $\mathrm{Re}$ on the reef slope ranged from $-60.81( \pm 4.73)$ to -97.37 $( \pm 24.50) \mathrm{mmol} \mathrm{O}_{2} \mathrm{~m}^{-2} \mathrm{~d}^{-1}$ and $-112.76( \pm 17.09)$ to $\left(-204.52( \pm 70.85) \mathrm{mmol} \mathrm{O}_{2} \mathrm{~m}^{-2} \mathrm{~d}^{-1}\right.$ for the reef flat. The results, however were not significantly different between either sites or seasons $(p>0.05)$.
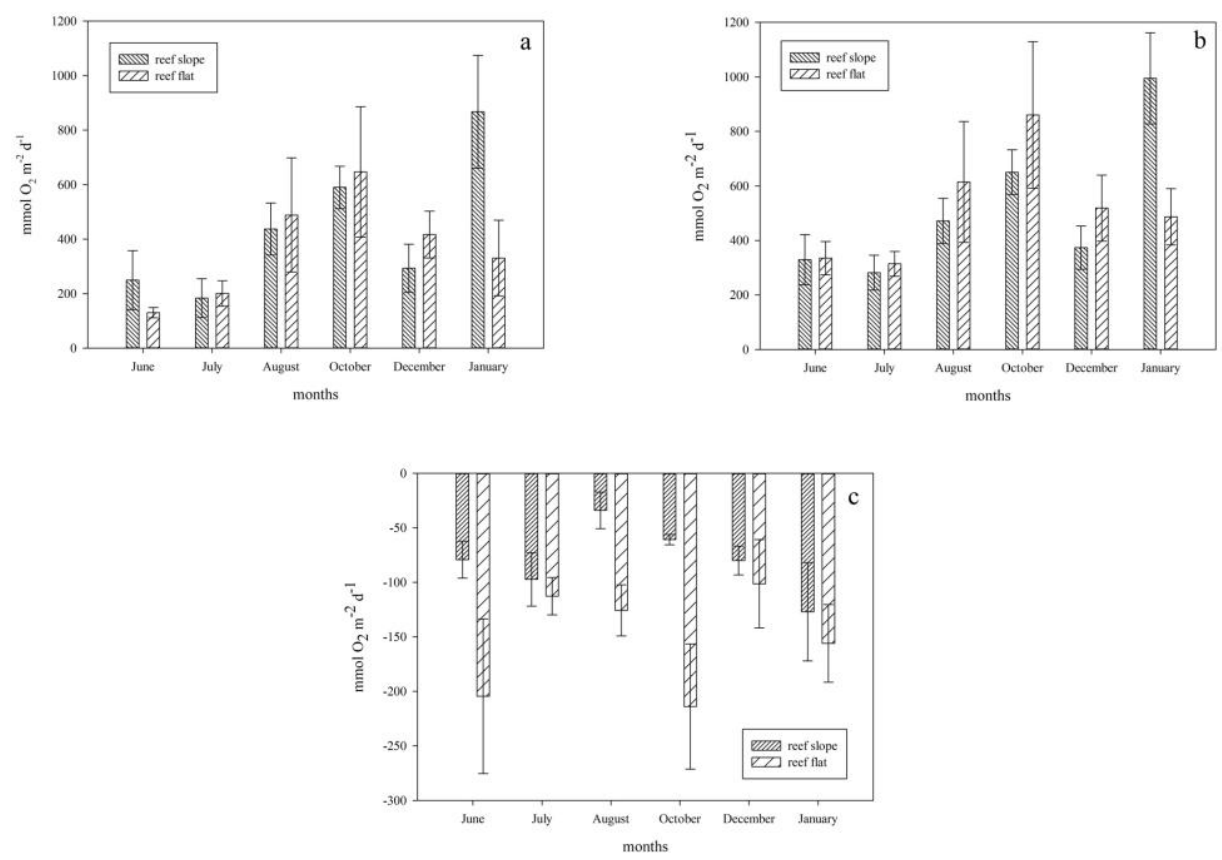

Figure 5. Net ecosystem metabolism (NEM) (a), Gross ecosystem metabolism (GEM) (b) and respiration $(R e)(c)$ of $P$. acuta from reef flat and reef slope. Data represents Mean $\pm S E(n=3)$ 


\section{Photosynthetic performance}

The $\Delta \mathrm{F} / \mathrm{F}_{\mathrm{m}}$, on the reef slope ranged from $0.640( \pm 0.010)$ to $0.661( \pm 0.010)$ and $0.614( \pm 0.017)$ to $0.661( \pm 0.010)$ for reef flat $($ Fig. $6 a)$. The $\Delta \mathrm{F} / \mathrm{F}_{\mathrm{m}}$, of coral on the reef slope was significantly higher than that on the flat in both seasons $(p=0.002)$ (Appendix Table 2).
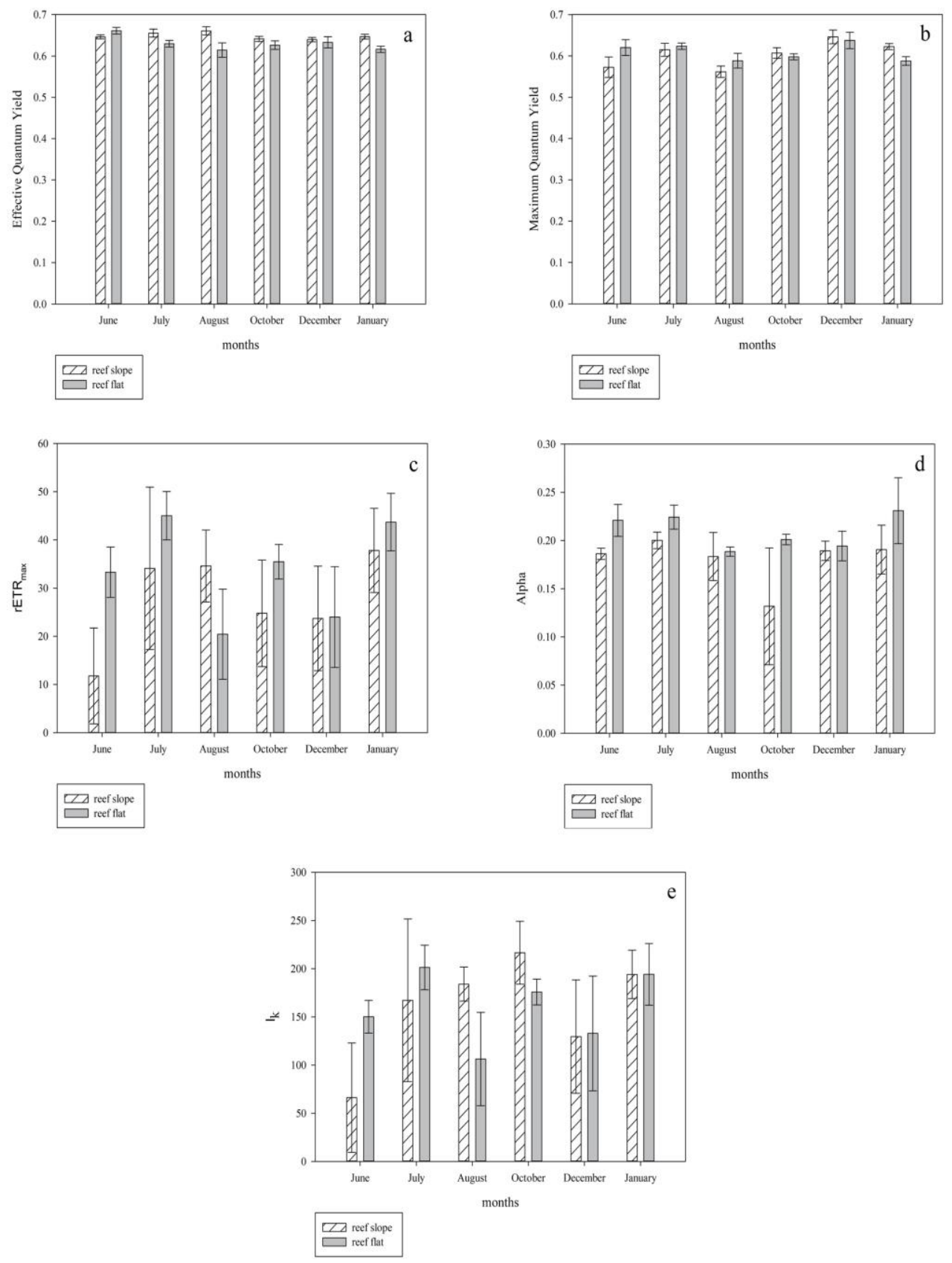

Figure 6. Photosynthetic performance (effective quantum yield of PSII $\left(\Delta F / F_{m}\right)(a)$, Maximum quantum yield of PSII $\left.\left(F_{v} / F_{m}\right)(b)\right)$, maximum relative electron transport rate $\left(r E T R_{\max }\right)(c)$, initial slope $(\alpha)(d)$ ) and minimum saturating irradiance $\left(I_{k}\right)(e)$ of $P$. acuta from reef flat and reef slope. Data represents Mean $\pm S E(n=4)$ 
While the $F_{\mathrm{v}} / \mathrm{F}_{\mathrm{m}}$ showed its maximum of the range at December $(0.646( \pm 0.017)$ and $0.637( \pm 0.020))$, minimum of the range at August $(0.562( \pm 0.014)$ and $0.588( \pm 0.018))$ for the reef slope and flat, respectively (Fig. $6 b$ ). The $\mathrm{F}_{\mathrm{v}} / \mathrm{F}_{\mathrm{m}}$ of the corals on the reef flat was significantly lower than that for the reef slope in the dry season as well as being higher in the wet season $(p=0.034)$ (Appendix Table 2$)$.

The average rETR $_{\max }$ (Fig. 6c) of the corals on the reef slope in both the wet and dry seasons tended to be higher than those on the reef flat but there was no significant difference between either sites or seasons $(p>0.05)$. However, the Initial slope $(\alpha)$ of the corals on the reef flat was significantly higher than that on the slope $(p=0.037)$ (Appendix Table 2).

The $\mathrm{I}_{\mathrm{k}}$ ranged from 66.19 to $216.68 \mu \mathrm{mol}$ photons $\mathrm{m}^{-2} \mathrm{~s}^{-1}$ for corals on the reef slope and 106.33 to $201.32 \mu \mathrm{mol}$ photons $\mathrm{m}^{-2} \mathrm{~s}^{-1}$ for those on the reef flat (Fig. 6e). However, the results produced no significant differences between either sites or seasons $(p>0.05)$.

\section{Symbiont density}

The cell density of corals on the reef slope and flat was in the range of $4.55 \times 10^{6}$ $\left( \pm 0.97 \times 10^{6}\right)$ to $11.84 \times 10^{6}\left( \pm 3.88 \times 10^{6}\right)$ cells $\mathrm{cm}^{-2}$ and $2.96 \times 10^{6}\left( \pm 0.83 \times 10^{6}\right)$ to $6.84 \times 10^{6}\left( \pm 0.69 \times 10^{6}\right)$ cells $\mathrm{cm}^{-2}$, respectively (Fig. 7). However, there were no significant differences between either sites or seasons $(p>0.05)$.

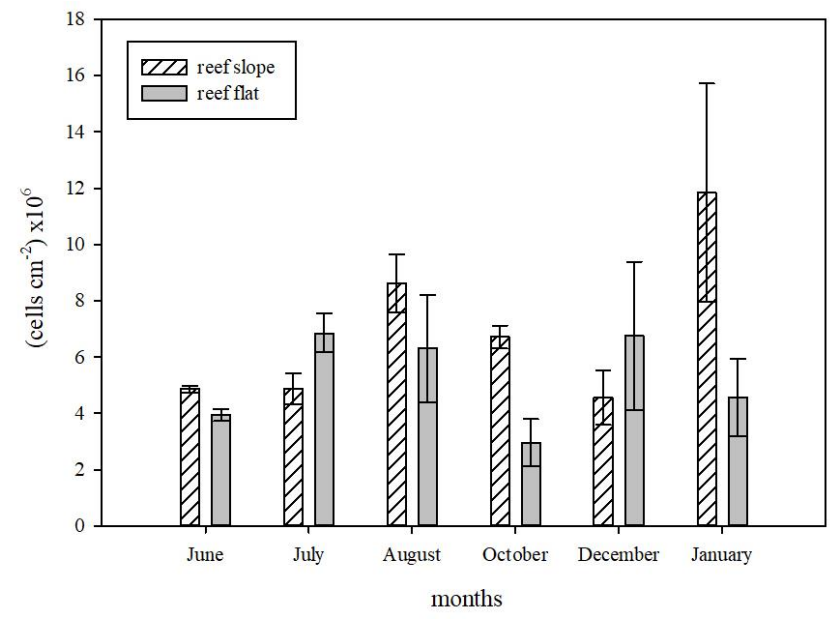

Figure 7. Symbiont density of $P$. acuta from reef flat and reef slope. Data represents Mean $\pm S E$ $(n=4)$

\section{Chlorophyll $a$ and $c_{2}$}

The chlorophyll $a$ of $P$. acuta corals on the reef slope ranged from $0.016( \pm 0.005)$ to $0.071( \pm 0.013) \mu \mathrm{g} \mathrm{mm}^{-2}$ and on the reef flat ranged from $0.023( \pm 0.005)$ to 0.047 $( \pm 0.017) \mathrm{\mu g} \mathrm{mm}^{-2}$ (Fig. 8a). While the Chlorophyll $c_{2}$ of corals on the reef slope ranged from $0.006( \pm 0.002)$ to $0.014( \pm 0.002) \mu \mathrm{g} \mathrm{mm}^{-2}$ and on the reef flat ranged from 0.005 $( \pm 0.001)$ to $0.039( \pm 0.031) \mu \mathrm{g} \mathrm{mm} \mathrm{mm}^{-2}$ (Fig. 8b). However, there were no significant differences between either sites or seasons $(p>0.05)$. 

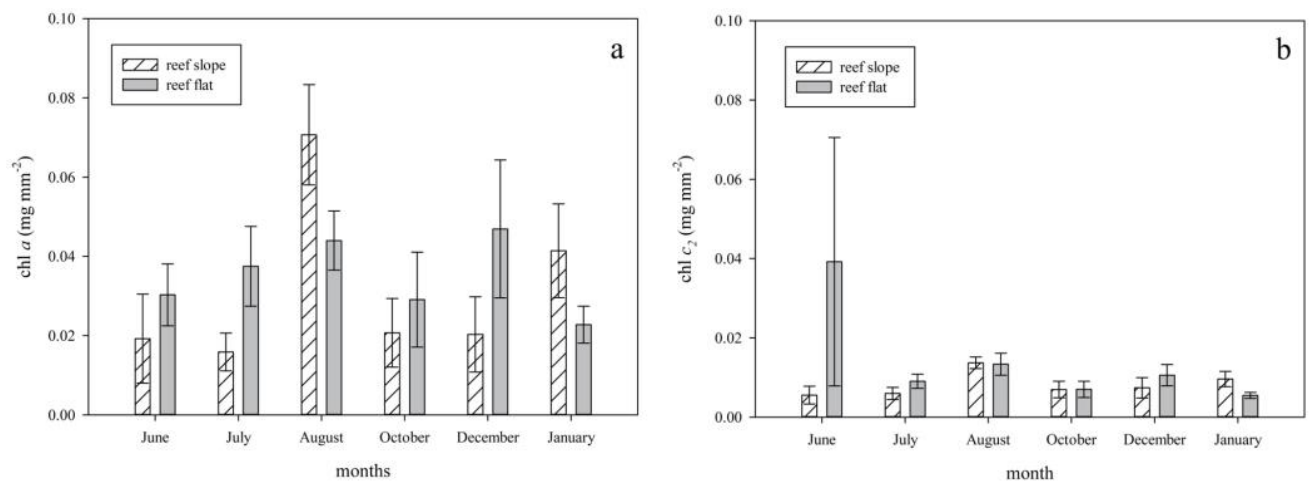

Figure 8. Chlorophyll $a(a)$ and $c_{2}(b)$ concentration of $P$. acuta from reefflat and reef slope. Data represents Mean $\pm S E(n=4)$

\section{Discussion}

\section{Coral diversity}

This is the first study of the coral photosynthesis and reef ecosystem metabolism of the southeast fringing reef of Phuket Island. The results showed more percentage cover of live coral but but less coral genera on the reef flat than the reef slope, which might be due to different levels of irradiance at different depths as suggested by Hughes et al. (2015), who found that light is the main factor affecting coral growth and zonation. In the present study the light intensity on the reef flat was noted to be double that on the reef slope. Higher Shannon's diversity indexes on the reef slope (2.67) suggested that there was more coral diversity there than on the reef flat. This is due to differences in physical parameters such as the sediment accumulation rate, light availability and depth, which are limiting factors for different coral species (Kahng et al., 2019) with different levels of resilience (Putnam et al., 2017). Slow growing massive corals, such as Porites sp. and Goniastrea sp. can survive in conditions of air exposure (Meixia et al., 2008) and demonstrate more tolerance to a changing environment (van Woesik et al., 2011). In contrast, fast growing, branching species, such as Acropora sp. and Pocillopora sp. (Al-Sofyani and Floos, 2013), prefer a limited range of temperatures (Williams et al., 2017), but have a greater ability to adapt to higher sediment accumulation rates because of their ability to self-clean (Duckworth et al., 2017). Consistent with Brown et al. (1999), the results of the present study show that massive coral species dominate the reefs because they are physiologically adapted to intertidal living. Moreover, Meixia et al. (2008) showed similar results, finding that Porites lutea was the dominant species with zonal characteristics with more coral species occurring on the reef slope than the reef flat.

\section{Ecosystem metabolisms}

Ecosystem metabolism is a biomass indicator which reflects energy storage in coral and the health of corals in each area, as well as how corals act as a carbon sink. The factors which affect ecosystem metabolism in the ocean are the light intensity, the time of day or year, the weather (Sathyendranath and Platt, 2001), adaptation of phytoplankton, the temperature and the available nutrients. The main factor is light intensity (Hughes et al., 2015) and that is usually correlated with depth. 
The NEM showed seasonal variation with higher metabolism in the dry season (Appendix Table 2). When the light intensity data (measured with a HOBO data logger) was compared, it was found that the reef flat had twice the light intensity of the reef slope which led to a higher rate of metabolism. The lower light intensity on the reef slope is caused by greater water depth reducing the light intensity (Kahng et al., 2019). Irradiance is important for photosynthesis of symbiotic algae living with corals and coral reefs metabolisms (Iluz and Dubinsky, 2015) and affect dissolved oxygen which is an indicator of coral reef metabolism (Camp et al., 2015). Moreover, the sediment accumulation rate on the reef slope $\left(11.76 \mathrm{~g} \mathrm{~m}^{-2} \mathrm{~d}^{-1}\right)$ was three times higher than that on the reef flat $\left(3.70 \mathrm{~g} \mathrm{~m}^{-2} \mathrm{~d}^{-1}\right)$. A high sediment accumulation rate can reduce the light intensity which is the main factor in zooxanthellae's photosynthesis and ecosystem metabolism (Iluz and Dubinsky, 2015). Differences in sediment accumulation rates depend on seasonal variation and weather (Browne et al., 2019). Furthermore, biological characteristics such as the percentage of live coral cover, macroalgae and cyanobacteria also affect the NEM. This study revealed that the reef flat had a greater percentage of live coral cover, macroalgae and cyanobacteria than the reef slope which led to a higher NEM.

The results of the present study were also broadly similar in respect of oxygen evolution (130.79-867.41 $\mathrm{mmol} \mathrm{O}_{2} \mathrm{~m}^{-2} \mathrm{~d}^{-1}$ ) to those of Camp et al. (2015) who found that the ecosystem metabolic activity ( $\mathrm{P}, \mathrm{R}$ and $\mathrm{G}$ ) of three coral species, Mussismilia harttii, Siderastrea cf. stellata and Porites astreoides were in the range of 43.2-158.4 $\mathrm{mmol} \mathrm{O}_{2} \mathrm{~m}^{-2} \mathrm{~d}^{-1}$. Moreover, all the ratios of GEM to Re were higher than 1 indicating that this ecosystem is autotrophic and that $P$. acuta is an important species in high productivity coral reef ecosystems.

\section{Photosynthesis efficiency}

Seasonal or spatial variation in photosynthesis and the photosynthetic capacity of corals have been observed in previous studies (Levy et al., 2004; Kuffner, 2005; Ulstrup et al., 2011; Sawall et al., 2014). These variations occur due to changes in environmental factors such as light intensity (Iluz and Dubinsky, 2015), temperature (Levy et al., 2004; Caroselli et al., 2015), salinity (Sandoval-Gil et al., 2012), sediment accumulation rate (Rogers, 1990), water velocity (Lesser et al., 1994) and other chemical factors (Redfield, 1958).

Browne et al. (2015) estimated the coral health of four common inshore reef corals in response to seasonal and anthropogenic changes in water quality, and found that temperature has the greatest influence on branching coral ( $P$. damicornis). Moreover, higher sedimentation rate and nutrient availability in the rainy season might affect coral health and physiology (Brown et al., 1999).

The $\Delta \mathrm{F} / \mathrm{F}_{\mathrm{m}}$, of $P$. acuta in this study showed spatial variation in both seasons suggesting that coral on the reef slope has higher photosynthesis efficiency than that of the reef flat since there is higher light intensity on the reef flat ( $\mathrm{ca} .600 \mu \mathrm{mol}$ photons $\mathrm{m}^{-2} \mathrm{~s}^{-1}$ ) and this value exceeded the $\mathrm{I}_{\mathrm{k}}$ (Fig. 6e) at the same site leading to photoinhibition in the reef-flat coral. While the light intensity on the reef slope ( $c a .300$ $\mu \mathrm{mol}$ photons $\mathrm{m}^{-2} \mathrm{~s}^{-1}$ ) was lower it was closer to the $\mathrm{I}_{\mathrm{k}}$ than the light intensity on the reef flat, which means that although photoinhibition still occurs, it is of less effect. Therefore, the photosynthesis of symbionts on the reef slope is more efficient. Further, when comparing between seasons, the results showed higher photosynthesis efficiency for the coral on the reef slope in the wet season since the $\Delta \mathrm{F} / \mathrm{F}_{\mathrm{m}}$, and $\mathrm{I}_{\mathrm{k}}$ values were 
closer in the same season at each site. Moreover, diel variation of photosynthesis, which is down-regulated by intense light in the afternoon (Hill and Ralph, 2005) also reduced the $\Delta \mathrm{F} / \mathrm{F}_{\mathrm{m}}$, in this study.

On the other hand, no significant difference of $\Delta \mathrm{F} / \mathrm{F}_{\mathrm{m}}$ ' was noted on coral on the reef flat in different seasons since the shallow water condition meant that only highly tolerant corals can survive. This finding is consistent with that relating to $F_{v} / F_{m}$, which showed the same pattern. $F_{\mathrm{v}} / \mathrm{F}_{\mathrm{m}}$ representing the photosynthetic capacity of zooxanthellae and indicating coral stresses. When compared between seasons, the coral on the reef flat showed no significant differences in respect of $\mathrm{F}_{\mathrm{v}} / \mathrm{F}_{\mathrm{m}}$. On the other hand, the coral on the reef slope showed high variation between seasons with the $F_{v} / F_{m}$ lower than that on the reef flat in the wet season but higher in the dry season. This might be due to the higher accumulation of sediment in the wet season. Sediment reduces the light available to coral and increases coral stress which is reflected in the $F_{v} / F_{m}$ (Zhao and $\mathrm{Yu}, 2014)$. A Similar trend were was found for the symbiont density and pigment content but these indices are not as sensitive as the $\mathrm{F}_{\mathrm{v}} / \mathrm{F}_{\mathrm{m}}$.

The initial slope $(\alpha)$ showed some spatial variation with the reef-flat coral $\alpha$ being greater in both seasons. The results showed that the reef-flat coral had a greater ability to harvest light and a higher photosynthetic ability, and these adaptations led to the reefflat corals higher photosynthesis efficiency. On the other hand, comparisons of symbiont density and pigment content did not show any significant differences between sites although the $\alpha$ values were different, indicating that the reef-slope corals were exposed to an unsuitable environment which did not allow them to adapt and led to photosynthetic stress.

The $\mathrm{I}_{\mathrm{k}}$ is one of the main factors which can reveal the adaptation of coral (Zhao and $\mathrm{Yu}, 2014)$. The present study found no significant difference in $\mathrm{I}_{\mathrm{k}}$ due to the high sediment accumulation rate on the reef slope $\left(76.11 \mathrm{~g} \mathrm{~m}^{-2} \mathrm{~d}^{-1}\right)$ (Appendix Table 3) which was three times as great as that on the reef flat $\left(70.3 \mathrm{~g} \mathrm{~m}^{-2} \mathrm{~d}^{-1}\right)$ (Appendix Table 4) and led to the corals being stressed. Sediment was one of many factors which reduced the photosynthesis efficiently of the reef-slope corals, while the lower sediment accumulation on the reef flat was more suitable and allowed the corals to adapt. The reef-flat corals with better $\alpha$ adaptation were able to reduce their pigments and zooxanthellae cells whereas the reef-slope corals did not do so and this resulted in the finding of no significant differences between either sites or seasons in the $I_{k}$ and rETR $_{\max }$ indices.

The effect of sediment on zooxanthellae photosynthesis was demonstrated in Philipp and Fabricius (2003) who showed that the $\Delta \mathrm{F} / \mathrm{F}_{\mathrm{m}}$ and $\mathrm{F}_{\mathrm{v}} / \mathrm{F}_{\mathrm{m}}$ respond to sediment (79-234 $\left.\mathrm{mg} \mathrm{cm} \mathrm{cm}^{-2}\right)$ and exposure time $(0-36 \mathrm{hr})$ by being reduced. In addition, the photosynthesis and adaptation of zooxanthellae are affected by depth. Mass et al. (2007) revealed that the adaptation of Stylophora pistillata through a depth range of 5-65 m produced a lower Re, $\mathrm{P}_{\max }, \mathrm{I}_{\mathrm{c}}$ and $\mathrm{I}_{\mathrm{k}}$ as the depth increased. On the other hand, the $\alpha$ increased with depth.

There is a limitation in using the Junior PAM (Walz GmbH, Effeltrich, Germany) since it is not a submersible device. Therefore, photosynthetic measurements that are not derived in situ might be in error, and this would affect the $\Delta \mathrm{F} / \mathrm{F}_{\mathrm{m}}$, representing the sensitivity to light intensity flux. Including dark adapted measurements before fitting the RLCs which might lead to the opening of all the reaction centers which would affect the $\mathrm{I}_{\mathrm{k}}$ and $\mathrm{rETR}_{\max }$ values, which in this study showed no significant differences between either sites or seasons. 


\section{Symbionts density and chlorophyll concentration}

The photosynthesis data, zooxanthellae cell density and chlorophyll concentration in the coral tissues were measured and the results produced no significant differences between either sites or seasons. This might be due to photo-acclimation of the zooxanthellae on the reef flat by reducing the numbers of cells and pigment (Cooper and Ulstrup, 2009) while the zooxanthellae on the reef slope did not, which might be due to the predominance of the Symbiodinium genotype (Hennige et al., 2009).

Cooper and Ulstrup (2009), who estimated the spatial variation in the photophysiology of the zooxanthellae of $P$. damicornis, found that photoacclimation occurred in both shallow and deep corals but via different mechanisms. Thus, to deal with changes in irradiance, changes in symbionts such as the size and the location of their zooxanthellae, the zooxanthellae density and the chlorophyll contents might have occurred (Zhao and Yu, 2014). In addition, Frade et al. (2007) found a correlation between the Symbiobinium genotype (clade) in the coral genus Madracis and the water depth, with clade B7 being a generalist while clades B13 and B15 were restricted to shallow and deepwater reef environments, respectively. There have also been found to be differences in terms of the photoacclimation response for each genotype (Hennige et al., 2009). Meanwhile, Philipp and Fabricius (2003) found that the cell density and pigment concentration of zooxanthellae per coral surface area decreased with increased amounts of sediment but the decrease was not as fast as those noted in the $\Delta \mathrm{F} / \mathrm{F}_{\mathrm{m}}$, and $\mathrm{F}_{\mathrm{v}} / \mathrm{F}_{\mathrm{m}}$.

The optimal zooxanthellae densities found in the present study were lower than those

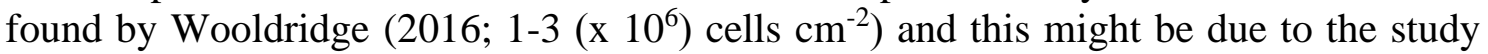
site being a marine attraction. Human activities, urban run off or wastewater could lead to high nutrient concentrations in the water, which can lead to an increase in cell density, pigment and maximum gross photosynthesis (Marubini and Davies, 1996). However, the rETR $_{\max }, \mathrm{I}_{\mathrm{k}}$, symbiont density and pigment showed no significant differences between sites or between seasons and this might be due to the better adaptation of reef-flat coral demonstrated by the reduced number of cells and pigment (Cooper and Ulstrup, 2009). Nevertheless, the environment on the reef slope was not suitable to adaptation by corals.

The lack of any correlation between ecosystem metabolism and zooxanthellae photosynthesis might be due to the assessment of ecosystem metabolism representing all living things in the chamber that including coral, algae and plankton, whereas photosynthesis was assessed based only on zooxanthellae.

\section{Chambers}

The design of the benthic chambers by which oxygen flux was measured described above in Materials and Methods entailed the limitation that its chamber shape was more suited to be deployed to collect data from branching or sub-massive coral or from coral where the colony size was smaller than the chamber. On the other hand, the design of the chamber was cost effective. Camp et al. (2015) used a flexible chamber to measure the ecosystem metabolic activity (P, R and G) of three coral species, Mussismilia harttii, Siderastrea cf. stellata and Porites astreoides. The results of that study produced values which were broadly similar to those produced by the present study. Further, Olivé et al. (2016) estimated the ecosystem metabolism using chambers in a seagrass meadow and the results were also broadly in-line with those from the present study. 


\section{Conclusion}

An assessment of GEM, NEM and Re was conducted in a tropical coral reef at the Southeast tip of Phuket Island, Thailand between June 2017 and January 2018. The findings of this study suggest that coral diversity is a result of a combination of light intensity, sediment accumulation, depth, other physical and chemical factors and ecosystem metabolism is mainly driven by the number of organisms, the light availability and depth.

Due to limitations of this chamber design, benthic oxygen flux chamber can estimate only in ecosystem scale and be deployed only on branching corals. The design of the chamber should be improved for measuring on various kinds of colony shape (e.g. plate, massive and branching). Real-time data collection on dissolved oxygen, irradiance and temperature inside the chamber could be developed.

This study provides a better understanding of how corals from different habitats respond to changes in season and are more susceptible to bleaching. The data from this study can be used for marine and coastal management and conservation.

Acknowledgements. This work is financially supported by the Coastal Oceanography and Climate Change Research Center, Prince of Songkla University, The Institute for the Promotion of Teaching Science and Technology (IPST; DPST Graduate with First Placement; Grant number: 006/2559), and National Research Council of Thailand (NRCT). We thank Assistant Professor Pattara Aiyarak and Professor Peter J. Ralph for support. We thank the Marine and Coastal Resources Institute, and the Faculty of Environmental Management, Prince of Songkla University, Associate Professor Raymond Ritchie and Phuket Marine Biological Center for research facilities.

\section{REFERENCES}

[1] Al-Sofyani, A. A., Floos, Y. A. M. (2013): Effect of temperature on two reef-building corals Pocillopora damicornis and P. verrucosa in the Red Sea. - Oceanologia 55(4): 917-935.

[2] Alva-Basurto, J. C., Arias-González, J. E. (2014): Modelling the effects of climate change on a Caribbean coral reef food web. - Ecological Modelling 289: 1-14.

[3] Barrón, C., Duarte, C. (2009): Dissolved organic matter release in a Posidonia oceanica meadow. - Marine Ecology Progress Series 374: 75-84.

[4] Brown, B., Dunne, R., Ambarsari, I., Le Tissier, M., Satapoomin, U. (1999): Seasonal fluctuations in environmental factors and variations in symbiotic algae and chlorophyll pigments in four Indo-Pacific coral species. - Marine Ecology Progress Series 191: 5369.

[5] Brown, B., Clarke, K., Warwick, R. (2002): Serial patterns of biodiversity change in corals across shallow reef flats in Ko Phuket, Thailand, due to the effects of local (sedimentation) and regional (climatic) perturbations. - Marine Biology 141(1): 21-29.

[6] Browne, N. K., Tay, J., Todd, P. A. (2015): Recreating pulsed turbidity events to determine coral-sediment thresholds for active management. - Journal of Experimental Marine Biology and Ecology 466 (Supplement C): 98-109.

[7] Browne, N., Braoun, C., McIlwain, J., Nagarajan, R., Zinke, J. (2019): Borneo coral reefs subject to high sediment loads show evidence of resilience to various environmental stressors. - PeerJ 7: e7382.

[8] Buddemeier, R. W., Baker, A. C., Fautin, D. G., Jacobs, J. R. (2004): The Adaptive Hypothesis of Bleaching. - In: Rosenberg, E., Loya, Y. (eds.) Coral Health and Disease. Springer Berlin Heidelberg, Berlin. 
[9] Camp, E. F., Krause, S.-L., Santos, L. M. F., Naumann, M. S., Kikuchi, R. K. P., Smith, D. J., Wild, C., Suggett, D. J. (2015): The "Flexi-Chamber": A Novel Cost-Effective In Situ Respirometry Chamber for Coral Physiological Measurements. - PLOS ONE 10(10): e0138800.

[10] Caroselli, E., Falini, G., Goffredo, S., Dubinsky, Z., Levy, O. (2015): Negative response of photosynthesis to natural and projected high seawater temperatures estimated by pulse amplitude modulation fluorometry in a temperate coral. - Frontiers in Physiology 6: 317.

[11] Cooper, T. F., Ulstrup, K. E. (2009): Mesoscale variation in the photophysiology of the reef building coral Pocillopora damicornis along an environmental gradient. - Estuarine, Coastal and Shelf Science 83(2): 186-196.

[12] Costanza, R., de Groot, R., Sutton, P., van der Ploeg, S., Anderson, S. J., Kubiszewski, I., Farber, S., Turner, R. K. (2014): Changes in the global value of ecosystem services. Global Environmental Change 26: 152-158.

[13] Crossland, C. J., Hatcher, B. G., Smith, S. V. (1991): Role of coral reefs in global ocean production. - Coral Reefs 10(2): 55-64.

[14] Cunning, R., Baker, A. C. (2013): Excess algal symbionts increase the susceptibility of reef corals to bleaching. - Nature Climate Change 3(3): 259-262.

[15] Douglas, A. E. (2010): The symbiotic habit. - Princeton University Press, Princeton.

[16] Downs, C. A., McDougall, K. E., Woodley, C. M., Fauth, J. E., Richmond, R. H., Kushmaro, A., Gibb, S. W., Loya, Y., Ostrander, G. K., Kramarsky-Winter, E. (2013): Heat-Stress and Light-Stress Induce Different Cellular Pathologies in the Symbiotic Dinoflagellate during Coral Bleaching. - PLOS ONE 8(12): e77173.

[17] Duckworth, A., Giofre, N., Jones, R. (2017): Coral morphology and sedimentation. Marine Pollution Bulletin 125(1-2): 289-300.

[18] Emanuel, K. (2005): Increasing destructiveness of tropical cyclones over the past 30 years. - Nature 436: 686.

[19] Falter, J. L., Lowe, R. J., Atkinson, M. J., Cuet, P. (2012): Seasonal coupling and decoupling of net calcification rates from coral reef metabolism and carbonate chemistry at Ningaloo Reef, Western Australia: coupling of reef calcification. - Journal of Geophysical Research: Oceans 117: C05003.

[20] Fitt, W. K., McFarland, F. K., Warner, M. E., Chilcoat, G. C. (2000): Seasonal patterns of tissue biomass and densities of symbiotic dinoflagellates in reef corals and relation to coral bleaching. - Limnology and Oceanography 45(3): 677-685.

[21] Frade, P. R., De Jongh, F., Vermeulen, F., Van Bleijswijk, J., Bak, R. P. M. (2007): Variation in symbiont distribution between closely related coral species over large depth ranges: coral symbiont distribution over large depths. - Molecular Ecology 17(2): 691703.

[22] Harrison, P. L., Booth, D. J. (2007): Coral reefs: naturally dynamic and increasingly disturbed ecosystems. - Marine ecology 2007(1): 316-377.

[23] Hennige, S. J., Suggett, D. J., Warner, M. E., McDougall, K. E., Smith, D. J. (2009): Photobiology of Symbiodinium revisited: bio-physical and bio-optical signatures. - Coral Reefs 28(1): 179-195.

[24] Hill, R., Ralph, P. J. (2005): Diel and seasonal changes in fluorescence rise kinetics of three scleractinian corals. - Functional Plant Biology 32(6): 549.

[25] Hill, R., Ralph, P. (2007): Post-bleaching viability of expelled zooxanthellae from the scleractinian coral Pocillopora damicornis. - Marine Ecology Progress Series 352: 137144.

[26] Hughes, R., Hughes, D., Smith, I., Dale, A. (2015): Oceanography and Marine Biology: An Annual Review, Volume 53. - Crc press, Boca raton.

[27] Iluz, D., Dubinsky, Z. (2015): Coral photobiology: new light on old views. - Zoology 118(2): 71-78. 
[28] Jokiel, P. L., Rodgers, K. S., Kuffner, I. B., Andersson, A. J., Cox, E. F., Mackenzie, F. T. (2008): Ocean acidification and calcifying reef organisms: a mesocosm investigation. - Coral Reefs 27(3): 473-483.

[29] Jokiel, P. L., Rodgers, K. S., Brown, E. K., Kenyon, J. C., Aeby, G., Smith, W. R., Farrell, F. (2015): Comparison of methods used to estimate coral cover in the Hawaiian Islands. - PeerJ 3: e954.

[30] Kahng, S. E., Akkaynak, D., Shlesinger, T., Hochberg, E. J., Wiedenmann, J., Tamir, R., Tchernov, D. (2019): Light, Temperature, Photosynthesis, Heterotrophy, and the Lower Depth Limits of Mesophotic Coral Ecosystems. - In: Loya, Y., Puglise, K. A., Bridge, T. C. L. (eds.) Mesophotic Coral Ecosystems. Springer International Publishing, Cham.

[31] Kayanne, H., Hata, H., Kudo, S., Yamano, H., Watanabe, A., Ikeda, Y., Nozaki, K., Kato, K., Negishi, A., Saito, H. (2005): Seasonal and bleaching-induced changes in coral reef metabolism and $\mathrm{CO}_{2}$ flux: coral reef metabolism and $\mathrm{CO}_{2}$ flux. - Global Biogeochemical Cycles 19(3): GB3015.

[32] Kohler, K. E., Gill, S. M. (2006): Coral Point Count with Excel extensions (CPCe): A Visual Basic program for the determination of coral and substrate coverage using random point count methodology. - Computers \& Geosciences 32(9): 1259-1269.

[33] Kuffner, I. B. (2005): Temporal Variation in Photosynthetic Pigments and UV-Absorbing Compounds in Shallow Populations of Two Hawaiian Reef Corals. - Pacific Science 59(4): 561-580.

[34] Lesser, M. P., Weis, V. M., Patterson, M. R., Jokiel, P. L. (1994): Effects of morphology and water motion on carbon delivery and productivity in the reef coral, Pocillopora damicornis (Linnaeus): Diffusion barriers, inorganic carbon limitation, and biochemical plasticity. - Journal of Experimental Marine Biology and Ecology 178(2): 153-179.

[35] Lesser, M. P. (2011): Coral Bleaching: Causes and Mechanisms. - In: Dubinsky, Z., Stambler, N. (eds.) Coral Reefs: An Ecosystem in Transition. Springer Netherlands, Dordrecht.

[36] Levy, O., Dubinsky, Z., Schneider, K., Achituv, Y., Zakai, D., Gorbunov, M. (2004): Diurnal hysteresis in coral photosynthesis. - Marine Ecology Progress Series 268: 105117.

[37] Li, L., Aro, E.-M., Millar, A. H. (2018): Mechanisms of Photodamage and Protein Turnover in Photoinhibition. - Trends in Plant Science 23(8): 667-676.

[38] Madduppa, H., Zamani, N. (2011): A Standard Criteria for Assesing the Health of Coral Reefs: Implication for Management and Conservation. - Journal of Indonesia Coral Reefs 1: 137-146.

[39] Marubini, F., Davies, P. S. (1996): Nitrate increases zooxanthellae population density and reduces skeletogenesis in corals. - Marine Biology 127(2): 319-328.

[40] Mass, T., Einbinder, S., Brokovich, E., Shashar, N., Vago, R., Erez, J., Dubinsky, Z. (2007): Photoacclimation of Stylophora pistillata to light extremes: metabolism and calcification. - Marine Ecology Progress Series 334: 93-102.

[41] Mass, T., Kline, D. I., Roopin, M., Veal, C. J., Cohen, S., Iluz, D., Levy, O. (2010): The spectral quality of light is a key driver of photosynthesis and photoadaptation in Stylophora pistillata colonies from different depths in the Red Sea. - Journal of Experimental Biology 213(23): 4084-4091.

[42] Meixia, Z., Kefu, Y., Qiaomin, Z., Qi, S. (2008): Spatial pattern of coral diversity in Luhuitou fringing reef, Sanya, China. - Acta Ecologica Sinica 28(4): 1419-1428.

[43] Moberg, F., Folke, C. (1999): Ecological goods and services of coral reef ecosystems. Ecological Economics 29(2): 215-233.

[44] Olivé, I., Silva, J., Costa, M. M., Santos, R. (2016): Estimating Seagrass Community Metabolism Using Benthic Chambers: The Effect of Incubation Time. - Estuaries and Coasts 39(1): 138-144. 
[45] Philipp, E., Fabricius, K. (2003): Photophysiological stress in scleractinian corals in response to short-term sedimentation. - Journal of Experimental Marine Biology and Ecology 287(1): 57-78.

[46] Pratchett, M. S., McCowan, D., Maynard, J. A., Heron, S. F. (2013): Changes in Bleaching Susceptibility among Corals Subject to Ocean Warming and Recurrent Bleaching in Moorea, French Polynesia. - PLoS ONE 8(7): e70443.

[47] Putnam, H. M., Barott, K. L., Ainsworth, T. D., Gates, R. D. (2017): The Vulnerability and Resilience of Reef-Building Corals. - Current Biology 27(11): R528-R540.

[48] Ralph, P. J., Gademann, R. (2005): Rapid light curves: A powerful tool to assess photosynthetic activity. - Aquatic Botany 82(3): 222-237.

[49] Randall, C. J., Szmant, A. M. (2009): Elevated Temperature Affects Development, Survivorship, and Settlement of the Elkhorn Coral, Acropora palmata (Lamarck 1816). The Biological Bulletin 217(3): 269-282.

[50] Redfield, A. C. (1958): The biological control of chemical factors in the environment. American Scientist 46(3): 230A-221.

[51] Ritchie, R. J. (2006): Consistent Sets of Spectrophotometric Chlorophyll Equations for Acetone, Methanol and Ethanol Solvents. - Photosynthesis Research 89(1): 27-41.

[52] Rogers, C. (1990): Responses of coral reefs and reef organisms to sedimentation. Marine Ecology Progress Series 62: 185-202.

[53] Sandoval-Gil, J. M., Marín-Guirao, L., Ruiz, J. M. (2012): The effect of salinity increase on the photosynthesis, growth and survival of the Mediterranean seagrass Cymodocea nodosa. - Estuarine, Coastal and Shelf Science 115: 260-271.

[54] Sathyendranath, S., Platt, T. (2001): Primary Production Distribution. - In: Steele, J. H., Thorpe, S. A., Turekian, K. K. (eds.) Encyclopedia of Ocean Sciences. Elsevier. Dalhousie University, NS, Canada.

[55] Sawall, Y., Al-Sofyani, A., Banguera-Hinestroza, E., Voolstra, C. R. (2014): SpatioTemporal Analyses of Symbiodinium Physiology of the Coral Pocillopora verrucosa along Large-Scale Nutrient and Temperature Gradients in the Red Sea. - PLOS ONE 9(8): e103179.

[56] Schreiber, U. (2004): Pulse-Amplitude-Modulation (PAM) Fluorometry and Saturation Pulse Method: An Overview. - In: Papageorgiou, G. C., Govindjee (eds.) Chlorophyll a Fluorescence. Springer Netherlands. Dordrecht.

[57] Slavov, C., Schrameyer, V., Reus, M., Ralph, P. J., Hill, R., Büchel, C., Larkum, A. W. D., Holzwarth, A. R. (2016): "Super-quenching" state protects Symbiodinium from thermal stress - Implications for coral bleaching. - Biochimica et Biophysica Acta (BBA) - Bioenergetics 1857(6): 840-847.

[58] Solomon, S. (2007): Climate change 2007: the physical science basis. - Working group I contribution to the fourth assessment report of the Intergovernmental Panel on Climate Change. Cambridge university press. New York.

[59] Smith, J. E., Shaw, M., Edwards, R. A., Obura, D., Pantos, O., Sala, E., Sandin, S. A., Smriga, S., Hatay, M., Rohwer, F. L. (2006): Indirect effects of algae on coral: algaemediated, microbe-induced coral mortality. - Ecology Letters 9(7): 835-845.

[60] Ulstrup, K., Kühl, M., van Oppen, M., Cooper, T., Ralph, P. (2011): Variation in photosynthesis and respiration in geographically distinct populations of two reef building coral species. - Aquatic Biology 12(3): 241-248.

[61] van Woesik, R., Sakai, K., Ganase, A., Loya, Y. (2011): Revisiting the winners and the losers a decade after coral bleaching. - Marine Ecology Progress Series 434: 67-76.

[62] Warner, M., Chilcoat, G., McFarland, F., Fitt, W. (2002): Seasonal fluctuations in the photosynthetic capacity of photosystem II in symbiotic dinoflagellates in the Caribbean reef-building coral Montastraea. - Marine Biology 141(1): 31-38.

[63] Williams, D. E., Miller, M. W., Bright, A. J., Pausch, R. E., Valdivia, A. (2017): Thermal stress exposure, bleaching response, and mortality in the threatened coral Acropora palmata. - Marine Pollution Bulletin 124(1): 189-197. 
[64] Winters, G., Holzman, R., Blekhman, A., Beer, S., Loya, Y. (2009): Photographic assessment of coral chlorophyll contents: Implications for ecophysiological studies and coral monitoring. - Journal of Experimental Marine Biology and Ecology 380(1-2): 25-35.

[65] Wooldridge, S. A. (2016): Excess seawater nutrients, enlarged algal symbiont densities and bleaching sensitive reef locations: 1. Identifying thresholds of concern for the Great Barrier Reef, Australia. - Marine Pollution Bulletin 114(1): 343-354.

[66] Yeemin, T., Pengsakun, S., Yucharoen, M., Klinthong, W., Sangmanee, K., Sutthacheep, M. (2013): Long-term changes in coral communities under stress from sediment. - Deep Sea Research Part II: Topical Studies in Oceanography 96: 32-40.

[67] Zhao, M., Yu, K. (2014): Application of chlorophyll fluorescence technique in the study of coral symbiotic zooxanthellae micro-ecology. - Acta Ecologica Sinica 34(3): 165-169.

\section{APPENDIX}

Table 1. Coral percentage cover at reef flat and reef slope for each genus. Data represents mean $( \pm S E)(n=3)$

\begin{tabular}{|c|c|c|c|}
\hline \multirow{2}{*}{ families } & \multirow{2}{*}{ genera } & \multicolumn{2}{|c|}{ coral percentage cover $\pm(\mathrm{SE})$} \\
\hline & & reef flat & reef slope \\
\hline \multirow[t]{2}{*}{ Poritidae } & Porites sp. & $31.38 \pm(4.79)$ & $5.05 \pm(2.34)$ \\
\hline & Goniopora sp. & $0.03 \pm(0.03)$ & $0.03 \pm(0.03)$ \\
\hline \multirow[t]{5}{*}{ Faviidae } & Favites sp. & $4.80 \pm(1.81)$ & $0.88 \pm(0.08)$ \\
\hline & Goniastrea sp. & $3.35 \pm(0.78)$ & $2.49 \pm(0.13)$ \\
\hline & Favia sp. & $0.54 \pm(0.09)$ & $0.91 \pm(0.14)$ \\
\hline & Diploastrea sp. & $0.29 \pm(0.20)$ & $0.16 \pm(0.03)$ \\
\hline & Cyphastrea sp. & $\mathrm{x}$ & $0.63 \pm(0.22)$ \\
\hline \multirow[t]{3}{*}{ Fungiidae } & Fungia sp. & $0.77 \pm(0.11)$ & $1.33 \pm(0.52)$ \\
\hline & Herpolitha sp. & $0.51 \pm(0.28)$ & $1.17 \pm(0.50)$ \\
\hline & Podabacia sp. & $0.19 \pm(0.14)$ & $0.25 \pm(0.03)$ \\
\hline Acroporidae & Acropora sp. & $0.76 \pm(0.62)$ & $2.84 \pm(1.04)$ \\
\hline Pocilloporiidae & Pocillopora sp. & $0.48 \pm(0.22)$ & $1.17 \pm(0.18)$ \\
\hline \multirow[t]{4}{*}{ Agariciidae } & Pavona sp. & $0.29 \pm(0.29)$ & $0.22 \pm(0.08)$ \\
\hline & Pachyseris sp. & $0.06 \pm(0.06)$ & $0.35 \pm(0.35)$ \\
\hline & Coeloseris sp. & $\mathrm{x}$ & $0.82 \pm(0.77)$ \\
\hline & Gardineroseris sp. & $\mathrm{x}$ & $0.09 \pm(0.09)$ \\
\hline \multirow[t]{2}{*}{ Merulinidae } & Merulina sp. & $0.26 \pm(0.26)$ & $0.57 \pm(0.27)$ \\
\hline & Hydnophora sp. & $0.13 \pm(0.13)$ & $0.28 \pm(0.16)$ \\
\hline \multirow[t]{2}{*}{ Mussidae } & Symphyllia sp. & $0.06 \pm(0.06)$ & $0.54 \pm(0.18)$ \\
\hline & Lobophyllia sp. & $\mathrm{x}$ & $0.57 \pm(0.36)$ \\
\hline Oculinidae & Galaxea sp. & $0.03 \pm(0.03)$ & $0.38 \pm(0.25)$ \\
\hline \multirow[t]{2}{*}{ Pectiniidae } & Pectinia sp. & $\mathrm{x}$ & $0.16 \pm(0.16)$ \\
\hline & Mycedium sp. & $\mathrm{x}$ & $0.28 \pm(0.20)$ \\
\hline Dendrophylliidae & Turbinaria sp. & $\mathrm{x}$ & $0.06 \pm(0.06)$ \\
\hline Dendrophylliidae & Turbinaria sp. & $\mathrm{x}$ & $0.06 \pm(0.06)$ \\
\hline Siderastreidae & Coscinaraea sp. & $\mathrm{x}$ & $0.41 \pm(0.41)$ \\
\hline
\end{tabular}

$\mathrm{x}=$ absent 
Table 2. Statistical indices of all parameters (Two-way ANOVA)

\begin{tabular}{c|c|c|c|c|c|c|c|c|c}
\hline \multirow{2}{*}{ Parameters } & \multicolumn{4}{|c|}{ Site } & \multicolumn{3}{c|}{ Season } & \multicolumn{3}{|c}{ Site*Season } \\
\cline { 2 - 9 } & df & F & sig & df & F & sig & df & F & sig \\
\hline GEM & 1 & 0.005 & 0.943 & 1 & 0.878 & 0.356 & 1 & 0.111 & 0.742 \\
NEM & 1 & 0.589 & 0.448 & 1 & 7.502 & $0.010^{*}$ & 1 & 0.330 & 0.570 \\
Re & 1 & 0.066 & 0.799 & 1 & 0.026 & 0.874 & 1 & 0.014 & 0.907 \\
$\mathbf{F}_{\mathbf{v}} \mathbf{F}_{\mathbf{m}}$ & 1 & 0.664 & 0.417 & 1 & 4.587 & $0.034^{*}$ & 1 & 6.197 & $0.014^{*}$ \\
$\Delta{\mathbf{F} / \mathbf{F}_{\mathbf{m}}}$ & 1 & 10.466 & $0.002^{*}$ & 1 & 3.539 & 0.062 & 1 & 0.025 & 0.874 \\
rETRmax & 1 & 1.072 & 0.308 & 1 & 0.091 & 0.765 & 1 & 0.002 & 0.968 \\
$\mathbf{I}_{\mathbf{k}}$ & 1 & 0.000 & 0.986 & 1 & 1.135 & 0.295 & 1 & 0.243 & 0.625 \\
Alpha & 1 & 4.763 & $0.037^{*}$ & 1 & 0.621 & 0.436 & 1 & 0.382 & 0.541 \\
Chl $\boldsymbol{a}$ & 1 & 0.255 & 0.617 & 1 & 0.679 & 0.416 & 1 & 0.055 & 0.816 \\
Chl $\boldsymbol{c}_{\mathbf{2}}$ & 1 & 1.266 & 0.269 & 1 & 1.595 & 0.216 & 1 & 1.396 & 0.246 \\
cell density & 1 & 2.433 & 0.129 & 1 & 0.090 & 0.766 & 1 & 1.361 & 0.252 \\
Salinity & 1 & 8.59 & $0.005^{*}$ & 1 & 62.427 & $<0.001^{*}$ & 1 & 9.069 & $0.004^{*}$ \\
Temperature & 1 & 0.025 & 0.876 & 1 & 1.209 & 0.275 & 1 & 4.521 & $0.037^{*}$ \\
pH & 1 & 0.001 & 0.976 & 1 & 23.016 & $<0.001^{*}$ & 1 & 0.054 & 0.817 \\
DO (mg/l) & 1 & 0.613 & 0.436 & 1 & 15.682 & $<0.001^{*}$ & 1 & 0.437 & 0.511 \\
DO (\%) & 1 & 1.621 & 0.207 & 1 & 0.060 & 0.807 & 1 & 1.790 & 0.185 \\
\hline
\end{tabular}

*significant different

Table 3. Environmental parameters on reef slope from June 2017 to January 2018. Data represents mean $( \pm S E)(n=3)$

\begin{tabular}{c|c|c|c|c|c|c}
\hline Months & $\begin{array}{c}\text { Salinity } \\
(\mathbf{P S U})\end{array}$ & $\begin{array}{c}\text { Temperature } \\
\left({ }^{\circ} \mathbf{C}\right)\end{array}$ & $\mathbf{p H}$ & $\begin{array}{c}\text { DO } \\
(\mathbf{m g} / \mathbf{l})\end{array}$ & $\begin{array}{c}\text { DO } \\
\mathbf{( \% )}\end{array}$ & $\begin{array}{c}\text { Sediment } \\
\text { accumulation } \\
\text { rate }\left(\mathbf{g ~ m}^{-2} \mathbf{d}^{-1}\right)\end{array}$ \\
\hline June & $32.00( \pm 0.00)$ & $31.13( \pm 0.14)$ & $8.11( \pm 0.01)$ & $7.09( \pm 0.09)$ & $95.67( \pm 1.12)$ & $\begin{array}{c}\mathrm{X} \\
\text { July }\end{array}$ \\
$34.00( \pm 0.00)$ & $30.00( \pm 0.00)$ & $7.26( \pm 0.00)$ & $7.19( \pm 0.14)$ & $95.03( \pm 2.00)$ & $15.86( \pm 8.16)$ \\
August & $32.99( \pm 0.03)$ & $31.35( \pm 0.02)$ & $8.19( \pm 0.02)$ & $5.53( \pm 0.03)$ & $91.80( \pm 0.66)$ & $17.93( \pm 16.68)$ \\
October & $32.87( \pm 0.05)$ & $30.40( \pm 0.00)$ & $8.23( \pm 0.01)$ & $5.73( \pm 0.23)$ & $91.75( \pm 3.59)$ & $1.49( \pm 0.39)$ \\
December & $32.00( \pm 0.04)$ & $30.42( \pm 0.08)$ & $8.16( \pm 0.01)$ & $6.08( \pm 0.18)$ & $96.97( \pm 2.85)$ & $\mathrm{x}$ \\
January & $31.90( \pm 0.03)$ & $29.10( \pm 0.03)$ & $8.17( \pm 0.00)$ & $5.60( \pm 0.17)$ & $87.57( \pm 2.59)$ & $\mathrm{x}$ \\
\hline
\end{tabular}

$\mathrm{x}=\mathrm{absent}$

Table 4. Environmental parameters on reef flat from June 2017 to January 2018. Data represents mean $( \pm S E)(n=3)$

\begin{tabular}{|c|c|c|c|c|c|c|}
\hline Months & $\begin{array}{l}\text { Salinity } \\
\text { (PSU) }\end{array}$ & $\begin{array}{c}\text { Temperature } \\
\left({ }^{\circ} \mathrm{C}\right)\end{array}$ & $\mathbf{p H}$ & $\begin{array}{c}\text { DO } \\
(\mathrm{mg} / \mathrm{l})\end{array}$ & $\begin{array}{l}\text { DO } \\
(\%)\end{array}$ & $\begin{array}{c}\text { Sediment } \\
\text { accumulation } \\
\text { rate }\left(\mathrm{g} \mathrm{m}^{-2} \mathrm{~d}^{-1}\right)\end{array}$ \\
\hline & & & & & $93.72( \pm 4.08)$ & $\mathrm{x}$ \\
\hline & & & & & & $4.13(=$ \\
\hline August & & & 8.17 & 5.75 & 95.33 & $4.63(=$ \\
\hline October & & 31. & $8.29( \pm$ & 5.67 & 92.53( & $2.34( \pm 0.78)$ \\
\hline December & $32.02( \pm$ & $30.65( \pm 0.0$ & $8.21( \pm 0.01)$ & $6.03( \pm 0.22)$ & $96.38( \pm 3.46)$ & $\mathrm{x}$ \\
\hline January & $31.92( \pm 0.03)$ & $29.80( \pm 0.20)$ & $8.13( \pm 0.02)$ & $6.46( \pm 0.37)$ & $102.22( \pm 5.97)$ & $\mathrm{x}$ \\
\hline
\end{tabular}

$\mathrm{x}=\mathrm{absent}$ 